\title{
PENGARUH PEMBERIAN PUDING KACANG MERAH (Vigna angularis) TERHADAP KADAR GLUKOSA DARAH PUASA, TEKANAN DARAH, DAN LINGKAR PINGGANG OBESITAS HIPERTENSI NON-HIPERTENSI PADA REMAJA PUTRI
}

\author{
Rita Nuryanti, Hesti Murwani Rahayuningsih*) \\ Program Studi Ilmu Gizi Fakultas Kedokteran Universitas Diponegoro \\ Jl.Dr.Sutomo No.18, Semarang, Telp (024) 8453708, Email : gizifk@undip.ac.id
}

\begin{abstract}
Background: The metabolic syndrome is a collective of metabolic abnormalities associated with an increased risk of cardiovascular disease. Red bean is a food source of fiber and low glycemic indexed. Arginine is an amino acid in the beans semiessential as substrates for the formation of NO can control blood pressure and trigger the release of insulin from the pancreas. This study aims to determine the effect of red bean pudding (Vigna angularis) on fasting blood glucose levels, blood pressure and waist circumference in young women obesity hypertension and non-hypertension in young women

Methods: The study was pre-experimental (the one group pretest-posttest design). Subjects were female students of class $X$ and XI of SMAN 2 Semarang with a BMI $\geq 95$ th percentile for BMI percentile charts of women aged 2-20 years, fasting glucose levels $\geq 100 \mathrm{mg} / \mathrm{dl}$, systolic blood pressure of 120-130 mm Hg and diastolic $80-89 \mathrm{~mm} \mathrm{Hg}$, waist circumference $\geq 80 \mathrm{~cm}$. Group of obesity hypertension and non-obese hypertensive got red bean pudding as much as 50 grams / day for 14 days. Enzymatic colorimetric method was used to analyze the levels of fasting blood glucose after fasting subjects $\pm 10-12$ hours. Blood pressure is checked using a mercury sphygmomanometer. Waist circumference was measured using a measuring tape / metlin. Normality using the Shapiro Wilk test. Statistical analysis using a dependent t-test, Wilcoxon, independent t-test and Mann Whitney.

Results: Obese hypertensive group did not experience a decrease in fasting blood glucose level $(p=0.210)$ and systolic blood pressure $(p=0.157)$. Obese non-hypertensive group decreased fasting blood glucose level $(p=0.021)$ at $6: 33 \pm 4.67 \mathrm{mg} / \mathrm{dl}$ and systolic blood pressure $(p=0.046)$ was $6.67 \pm 5.16 \mathrm{mmHg}$. Group of obese hypertensive and non-hypertensive not decreased waist circumference $(p=0.165, p=0.073)$. Statistically, there were no differences in changes in fasting blood glucose level $(p=0.147)$, systolic blood pressure $(p=0.096)$, diastolic blood pressure $(p=0.866)$ and waist circumference $(p=0.924)$ between groups of obese hypertensive and non-hypertensive. Conclusion: There is a red bean pudding effect on fasting blood glucose level and systolic blood pressure in nonhypertensive obese group. No red bean pudding influence on GDP levels and systolic blood pressure in obese hypertensive group. No red bean pudding influence on diastolic blood pressure and waist circumference in obese hypertensive group and non-hypertensive obese. There is no difference in fasting blood glucose level, blood pressure systolic diastolic blood pressure and waist circumference among obese hypertensive group and obese nonhypertensive group.
\end{abstract}

Keywords: obesity; hypertension; pudding; red beans; fasting blood glucose; blood pressure; waist circumference

\begin{abstract}
ABSTRAK
Latar Belakang : Sindrom metabolik adalah kumpulan kelainan metabolik yang dikaitkan dengan peningkatan risiko penyakit kardiovaskular. Kacang merah merupakan bahan makanan sumber serat dan berindeks glikemik rendah. Arginin merupakan asam amino semiessential dalam kacang merah sebagai substrat untuk pembentukan NO dapat mengontrol tekanan darah dan memicu pelepasan insulin dari pankreas. Penelitian ini bertujuan untuk mengetahui pengaruh puding kacang merah (Vigna angularis) terhadap kadar glukosa darah puasa, tekanan darah dan lingkar pinggang obesitas hipertensi non-hipertensi pada remaja putri

Metode : Jenis penelitian adalah pra-eksperimental (the one group pretest-posttest design). Subjek penelitian adalah siswi kelas X dan XI SMA Negeri 2 Semarang dengan IMT $\geq$ persentil ke-95 grafik persentil IMT untuk perempuan umur 2-20 tahun, kadar glukosa puasa $\geq 100 \mathrm{mg} / \mathrm{dl}$, tekanan darah sistolik 120-130 mm Hg dan diastolik 80-89 mm $H$, lingkar pinggang $\geq 80 \mathrm{~cm}$. Kelompok obesitas hipertensi dan obesitas non-hipertensi mendapat puding kacang merah sebanyak 50 gram/hari selama 14 hari. Metode enzymatic colorimetric digunakan untuk menganalisis kadar glukosa darah puasa setelah subjek berpuasa \pm 10-12 jam. Tekanan darah diperiksa menggunakan Sphygmomanometer air raksa. Lingkar pinggang diukur menggunakan pita ukur/metlin. Uji normalitas menggunakan Shapiro Wilk. Analisis statistik menggunakan dependent t-test, Wilcoxon, independent t-test dan Mann Whitney.

Hasil : Kelompok obesitas hipertensi tidak mengalami penurunan kadar GDP $(p=0.210)$ dan tekanan darah sistolik ( $p=0.157)$. Kelompok obesitas non-hipertensi mengalami penurunan kadar GDP (p=0.021) sebesar $6.33 \pm 4.67 \mathrm{mg} / \mathrm{dl}$ dan tekanan darah sistolik $(p=0.046)$ sebesar $6.67 \pm 5.16 \mathrm{mmHg}$. Kelompok obesitas hipertensi dan non-hipertensi tidak mengalami penurunan lingkar pinggang $(p=0.165 ; p=0.073)$. Secara statistik, tidak terdapat perbedaan
\end{abstract}

\footnotetext{
${ }^{*}$ Penulis Penanggungjawab
} 
perubahan kadar GDP ( $p=0.147)$, tekanan darah sistolik $(p=0.096)$, tekanan darah diastolik $(p=0.866)$ dan lingkar pinggang $(p=0.924)$ antara kelompok obesitas hipertensi dan non-hipertensi.

Kesimpulan : Ada pengaruh puding kacang merah terhadap kadar GDP dan tekanan darah sistolik pada kelompok obesitas non-hipertensi. Tidak ada pengaruh puding kacang merah terhadap kadar GDP dan tekanan darah sistolik pada kelompok obesitas hipertensi. Tidak ada pengaruh puding kacang merah terhadap tekanan darah diastolik dan lingkar pinggang pada kelompok obesitas hipertensi dan obesitas non-hipertensi. Tidak ada perbedaan kadar GDP, tekanan darah sistolik tekanan darah diastolik dan lingkar pinggang antara kelompok obesitas hipertensi dan kelompok obesitas non-hipertensi.

Kata kunci : obesitas; hipertensi; puding; kacang merah; glukosa darah puasa; tekanan darah; lingkar pinggang

\section{PENDAHULUAN}

Sindrom metabolik adalah kumpulan kelainan metabolik yang dikaitkan dengan peningkatan risiko penyakit kardiovaskular. $^{1}$ Menurut kriteria dari International Diabetes Federation (IDF), seorang remaja didefinisikan sebagai sindrom metabolik jika memiliki obesitas sentral, ditambah dua dari empat faktor tambahan berikut: peningkatan $\mathrm{TG}(>150 \mathrm{mg} / \mathrm{dl})$, penurunan kolesterol HDL ( $<40 \mathrm{mg} / \mathrm{dl}$ pada pria dan $<50 \mathrm{mg} / \mathrm{dl}$ pada wanita), peningkatan tekanan darah (tekanan darah sistolik $>130 \mathrm{mmHg}$ atau tekanan darah diastolik $>85 \mathrm{mmHg}$ ), peningkatan glukosa plasma puasa $(>100 \mathrm{mg} / \mathrm{dl}) .{ }^{2}$ Keadaan ini pada umumnya diawali dengan obesitas, terutama obesitas sentral. ${ }^{3}$ Kejadian sindrom metabolik meningkat seiring dengan meningkatnya kejadian obesitas. Penelitian di Bali (2003-2009) menunjukkan prevalensi sindrom metabolik yang lebih besar pada wanita yaitu $20 \%$, sedangkan pada pria $16,6 \% .^{4}$ Menurut Riset Kesehatan Dasar (Riskesdas) bahwa terjadi peningkatan prevalensi obesitas sentral remaja usia $\geq 15$ tahun pada tahun 2013 dibandingkan pada tahun 2007. Prevalensi obesitas sentral remaja tahun 2013 sebesar $26.6 \%$ lebih tinggi dari tahun 2007 sebesar $18.8 \% .^{5}$

Berbagai faktor dapat menjadi penyebab timbulnya obesitas pada remaja. Faktor-faktor yang signifikan dalam mempengaruhi kejadian obesitas adalah kelebihan asupan dan physical inactivity, yang nantinya akan memberikan andil dalam perkembangan sindrom metabolik. ${ }^{6}$ Kelebihan energi yang dikonsumsi tanpa disertai penggunaan energi yang memadai akan menyebabkan peningkatan penyimpanan energi dalam sel lemak yang berakibat meningkatnya jumlah dan ukuran sel lemak. Keadaan ini yang mengakibatkan obesitas. $^{7}$

Salah satu cara alternatif pencegahan sindrom metabolik yang murah dan aman adalah terapi diet dengan mengonsumsi makanan tinggi serat dan berindeks glikemik rendah. ${ }^{8}$ Kacang merah merupakan salah satu bahan makanan yang merupakan sumber serat dan berindeks glikemik rendah. ${ }^{9,10,11}$ Kacang merah memiliki indeks glikemik yaitu $26 .{ }^{9}$ Serat dianggap mempunyai efek hipoglikemik karena mampu memperlambat pengosongan lambung, mengubah peristaltik lambung, memperlambat difusi glukosa, menurunkan aktifitas $\alpha$-amilase akibat meningkatnya viskositas isi usus, dan menurunkan waktu transit yang mengakibatkan pendeknya absorbsi glukosa ${ }^{12}$ dan berpengaruh terhadap peningkatan sekresi insulin dan pemakaian glukosa oleh sel hati, dengan demikian kadar gula darah menjadi berkurang. ${ }^{13}$ Peran pangan yang berindeks glikemik rendah adalah akan dicerna dan diubah menjadi glukosa secara bertahap dan perlahan, sehingga puncak kadar glukosa darah juga akan rendah yang berarti fluktuasi peningkatan kadar glukosa darah relatif pendek. ${ }^{14}$

Puding kacang merah adalah makanan berbentuk cairan yang kemudian diolah menjadi bentuk padat, setelah dicampur dengan kacang merah dan agar-agar (karagenan). ${ }^{15}$ Berbagai proses pengolahan atau pemasakan dapat mempengaruhi komposisi zat gizi penyusun pangan, komposisi kimia, zat inhibitor yang selanjutnya dapat mempengaruhi daya serap pangan tersebut. . $^{80,16}$ Proses pemasakan yang dilakukan adalah dikukus. Pada proses pemasakan tersebut akan mempengaruhi kandungan air dan lemak yang akan mempengaruhi nilai indeks glikemik pangan. ${ }^{8,16}$

Arginin merupakan asam amino semiessential yang ditemukan dalam sumber makanan seperti kacang merah. ${ }^{17}$ Arginin dapat mengontrol tekanan darah dengan sejumlah cara. Pertama, arginin sebagai substrat untuk pembentukan NO. L-arginin adalah asam amino semi-esensial dan substrat untuk NOS dalam produksi nitrit oksida (NO). ${ }^{18}$ Kedua, arginin dapat meningkatkan pelepasan insulin dari pankreas. ${ }^{19}$ Insulin dapat menstimulasi uptake seluler dari arginin dengan mengurangi konsentrasi plasma dari asymmetrical dimethyl arginine (ADMA). ${ }^{19}$

Penelitian mengenai puding kacang merah (Vigna angularis) terhadap kadar glukosa darah puasa, tekanan darah dan lingkar pinggang pada remaja putri dengan risiko sindrom metabolik belum pernah dilakukan di Indonesia. Hal tersebut mendorong peneliti melakukan penelitian untuk melihat apakah terdapat pengaruh puding kacang 
merah (Vigna angularis) terhadap kadar glukosa darah puasa, tekanan darah dan lingkar pinggang pada remaja putri dengan risiko sindrom metabolik.

\section{METODE}

Penelitian ini dilakukan di SMA Negeri 2 Semarang pada bulan Mei 2014. Jenis penelitian adalah pra-eksperimental (the one group pretestposttest design). ${ }^{20}$ Subjek penelitian adalah siswi kelas X dan XI SMA Negeri 2 Semarang

Kriteria inklusi subjek antara lain wanita, usia 1518 tahun yang mengalami obesitas ditandai dengan IMT $\geq$ persentil ke-95 grafik persentil IMT untuk perempuan umur 2-20 tahun, kadar glukosa puasa $\geq 100 \mathrm{mg} / \mathrm{dl}$, tekanan darah sistolik $120-130 \mathrm{~mm} \mathrm{Hg}$ dan diastolik 80-89 $\mathrm{mm} \mathrm{Hg}$, lingkar pinggang $\geq 80$ $\mathrm{cm}$ dan bersedia menjadi sampel dengan mengisi informed consent. Kriteria eksklusi adalah meninggal saat penelitian berlangsung dan mengundurkan diri saat penelitian berlangsung.

Prosedur pertama dalam penelitian ini adalah melakukan skrining untuk menentukan subjek penelitian dilakukan terhadap 458 siswi dengan pengukuran antropometri yaitu berat badan (BB), tinggi badan (TB). BB diukur menggunakan timbangan berat badan dengan ketelitian $0,1 \mathrm{~kg}$, dan TB diukur menggunakan microtoise dengan ketelitian $0,1 \mathrm{~cm}$. Pengukuran lingkar pinggang (LP) untuk menentukan keadaan obesitas sentral, LP diukur menggunakan pita ukur/metlin dengan ukuran maksimal $150 \mathrm{~cm}$. Penentuan obesitas sentral ditentukan apabila nilai LP pada perempuan $\geq$ persentil ke- $90 .{ }^{21}$

Sebanyak 19 subjek yang memenuhi kriteria inklusi, namun hanya 16 subjek yang bersedia diambil darahnya untuk pemeriksaan glukosa darah setelah intervensi. Subjek dibagi menjadi 2 kelompok menggunakan simple random sampling, yaitu kelompok obesitas hipertensi dan obesitas non-hipertensi. Akan tetapi sebanyak 1 orang subjek dari obesitas hipertensi mengundurkan diri karena ke luar kota sehingga jumlah subjek yang mengikuti penelitian hingga akhir sebanyak 15 orang dan memenuhi besar sampel minimal.

Masing-masing kelompok diberikan puding kacang merah sebanyak 50 gram selama 14 hari. Dosis pemberian puding kacang merah berdasarkan dosis yang diberikan pada penelitian sebelumnya yang dapat menurunkan kadar glukosa darah secara signifikan. Setelah pemberian puding kacang merah selama 14 hari, hari ke-15 dilakukan pengambilan darah, pemeriksaan tekanan darah dan lingkar pinggang pada kelompok obesitas hipertensi dan obesitas non-hipertensi. Kepatuhan dan waktu mengkonsumsi puding kacang merah kelompok obesitas hipertensi dan obesitas non-hipertensi dipantau dengan menggunakan formulir check list.

Variabel bebas adalah pemberian puding kacang merah. Kacang merah sebanyak 50 gram yang dikukus selama 30 menit, kemudian ditambahkan larutan agar-agar 150 cc. Puding kacang merah diberikan sekali dalam sehari pada saat istirahat selama 14 hari. Variabel terikat dalam penelitan ini adalah glukosa darah puasa, tekanan darah, dan lingkar pinggang. Variabel perancu adalah aktifitas fisik dan asupan makanan. Kadar glukosa darah puasa dengan satuan $\mathrm{mg} / \mathrm{dl}$ yang diambil oleh petugas laboratorium "P" menggunakan metode enzymatic colorimetric (Sigma Chemical Company, St. Louis, MO, USA) setelah subjek berpuasa $\pm 10-12$ jam. Data tekanan darah (TD) diperiksa petugas sebanyak 2 kali saat pretest dan posttest menggunakan Sphygmomanometer air raksa dengan ukuran cuff dan manset panjang 17,0 - 19,0 cm dan lebar 7,5$9,0 \mathrm{~cm}$. Tekanan darah diperiksa saat subjek duduk dengan tenang selama 5 menit. LP diukur menggunakan pita ukur/metlin dengan ukuran maksimal $150 \mathrm{~cm}$.

Variabel perancu adalah aktifitas fisik dan asupan makan selama penelitian. Data aktifitas fisik diperoleh melalui wawancara dengan menggunakan pedoman kuesioner International Physical Activity Questionnaire (IPAQ). Aktifitas fisik yang dilaporkan oleh subyek mencakup kegiatan yang hanya dilakukan selama tujuh hari terakhir. Skor aktifitas fisik dihitung sesuai dengan protokol skoring IPAQ dan dinyatakan dalam satuan METmenit/minggu. Kategori tingkat aktifitas fisik dalam tabel distribusi frekuensi yang diadopsi dari IPAQ, yaitu rendah ( $<600$ MET-menit/minggu), sedang (600-2999 MET-menit/minggu), dan tinggi ( $\geq 3000$ MET-menit/minggu). Data asupan makanan diperoleh melalui recall dengan formulir Food Recall 5x24 jam. Hasil recall dalam satuan ukuran rumah tangga (URT) dikonversi ke dalam satuan gram, lalu dianalisis dengan Nutrisurvey. Kebutuhan individu diperoleh dengan mengkonversikan Angka Kecukupan Gizi (AKG) untuk individu dengan cara membandingkan berat badan aktual dengan berat badan rujukan untuk usia 16-18 tahun pada tabel AKG 2013, kemudian dikalikan $100 \%$ maka didapatkan persen tingkat kecukupan asupan zat gizi. Tingkat asupan zat gizi dibagi menjadi 3 kategori, yaitu baik (>100\% AKG), sedang (81-99\% AKG), dan kurang $(<80 \%$ $\mathrm{AKG}){ }^{22}$

Data yang diperoleh dianalisis secara statistik. Gambaran karakteristik subjek dianalisis dengan analisis deskriptif. Uji normalitas data 
glukosa darah puasa tekanan darah dan lingkar pinggang sebelum dan setelah intervensi menggunakan uji Shapiro-Wilk. Perbedaan kadar glukosa darah puasa dan lingkar pinggang sebelum dan setelah intervensi pada kedua kelompok digunakan paired t-test, sedangkan untuk mengetahui perbedaan penurunan kadar glukosa darah puasa pada kelompok obesitas hipertensi dan obesitas non-hipertensi digunakan independent sample t-test. Perbedaan tekanan darah sistolik dan diastolik sebelum dan setelah intervensi pada kedua kelompok digunakan uji Wilcoxon, sedangkan untuk mengetahui perbedaan penurunan tekanan darah sistolik dan diastolik pada kelompok obesitas hipertensi dan obesitas non-hipertensi uji MannWhitney. Perbedaan asupan energi, protein, lemak, karbohidrat, serat, PUFA, natrium, kalium, kalsium dan magnesium antara kelompok obesitas hipertensi dan obesitas non-hipertensi selama intervensi digunakan independent sample t-test dan uji MannWhitney.

\section{HASIL PENELITIAN}

Karakteristik dan keadaan subjek pada awal penelitian disajikan pada tabel 1 untuk melihat homogenitas variabel antara kelompok obesitas hipertensi dan obesitas non-hipertensi.

Tabel 1. Karakteristik dan Keadaan Subjek pada Awal Penelitian

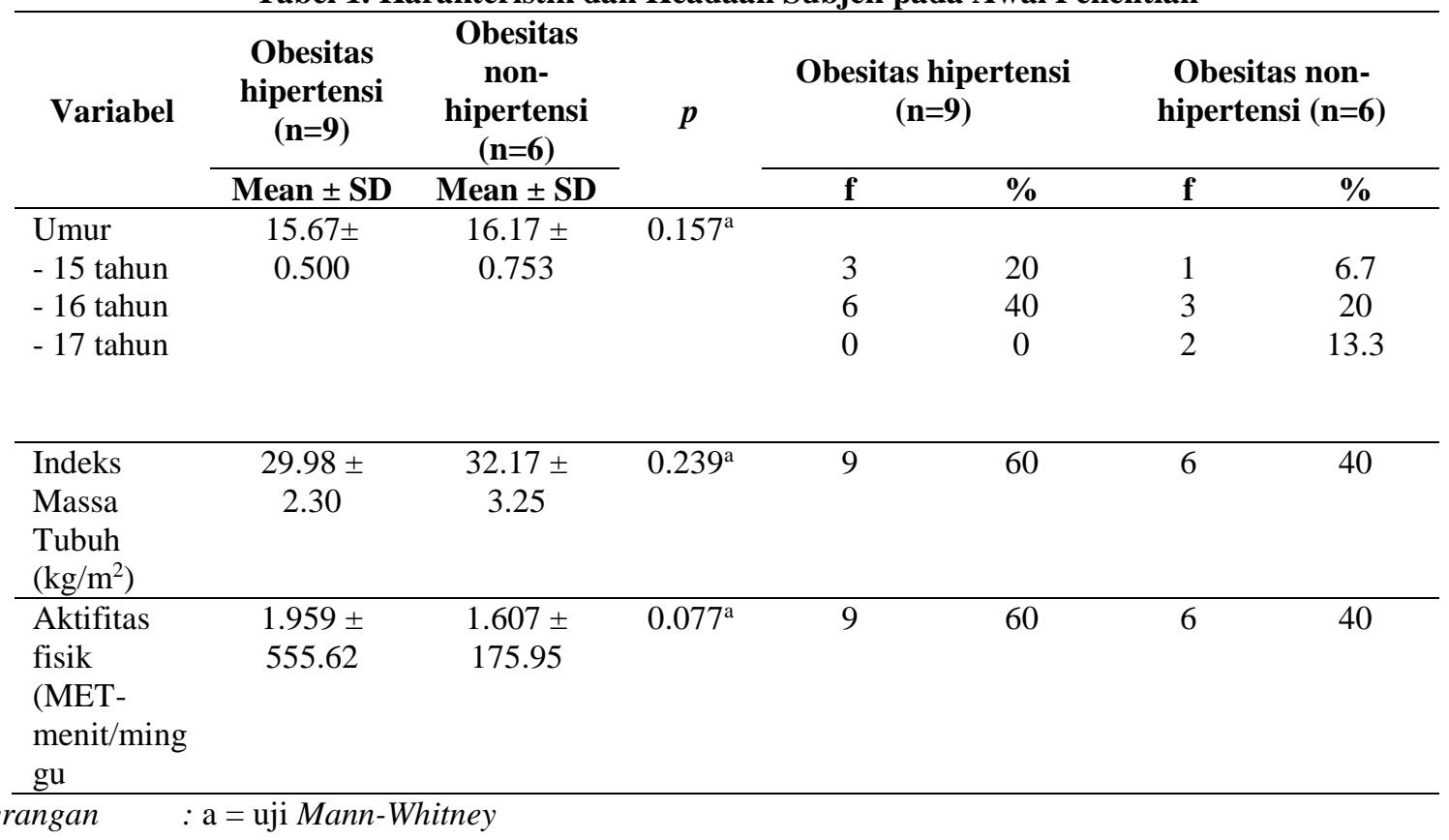

Tabel 1 menunjukkan sebagian besar subjek berada pada kelompok umur 16 tahun dan lebih banyak ditemukan pada kelompok obesitas hipertensi dibandingkan dengan kelompok obesitas non-hipertensi. Indeks massa tubuh (IMT) keseluruhan subjek tergolong obesitas. Aktifitas fisik keseluruhan subjek kategori sedang.

Berdasarkan uji Mann-Whitney, tidak terdapat perbedaan umur, IMT dan aktifitas fisik yang bermakna antara kelompok obesitas hipertensi dan obesitas non-hipertensi. Hal ini menggambarkan bahwa keadaan awal subjek penelitian adalah homogen.

Perbedaan Kadar Glukosa Darah Puasa Sebelum dan Setelah Intervensi

Tabel perbedaan kadar glukosa darah puasa sebelum dan setelah intervensi disajikan untuk melihat perubahan rerata kadar glukosa darah puasa kelompok obesitas hipertensi dan obesitas nonhipertensi sebelum dan setelah pemberian puding kacang merah selama 14 hari. 
Tabel 2. Perbedaan Kadar Glukosa Darah Puasa Sebelum dan Setelah Intervensi

\begin{tabular}{|c|c|c|c|c|c|}
\hline \multirow[b]{2}{*}{ Variabel } & \multicolumn{2}{|c|}{$\begin{array}{c}\text { Glukosa Darah Puasa } \\
\end{array}$} & \multirow[b]{2}{*}{$p^{\mathrm{a}}$} & \multirow[b]{2}{*}{$\begin{array}{c}\Delta \text { Glukosa } \\
\text { Darah Puasa }\end{array}$} & \multirow[b]{2}{*}{$p^{\mathbf{b}}$} \\
\hline & $\begin{array}{c}\text { Sebelum intervensi } \\
(\mathrm{mg} / \mathrm{dl})\end{array}$ & $\begin{array}{c}\text { Setelah intervensi } \\
(\mathrm{mg} / \mathrm{dl})\end{array}$ & & & \\
\hline $\begin{array}{l}\text { Obesitas } \\
\text { hipertensi } \\
(\mathrm{n}=9)\end{array}$ & & & & & \multirow{3}{*}{0.147} \\
\hline Mean \pm SD & $78.33 \pm 5.22$ & $75.44 \pm 3.67$ & 0.210 & $-2.88 \pm 6.35$ & \\
\hline $\begin{array}{l}\text { Obesitas non- } \\
\text { hipertensi } \\
\text { Mean } \pm \text { SD }\end{array}$ & $82.83 \pm 4.30$ & $76.50 \pm 2.49$ & 0.021 & $-6.33 \pm 4.67$ & \\
\hline
\end{tabular}

Keterangan $\quad: \mathrm{a}=$ paired $t$-test, $\mathrm{b}=$ independent $t$-test

Tabel 2 menunjukkan pada kelompok obesitas hipertensi tidak mengalami penurunan kadar glukosa darah puasa $(p>0.05)$ setelah pemberian puding kacang merah selama 14 hari yaitu sebesar $-2.88 \pm 6.35 \mathrm{mg} / \mathrm{dl}$. Kelompok obesitas non-hipertensi mengalami penurunan kadar glukosa darah puasa $(p<0.05)$ setelah pemberian puding kacang merah selama 14 hari yaitu sebesar $-6.33 \pm 4.67 \mathrm{mg} / \mathrm{dl}$.

Berdasarkan independent t-test, tidak terdapat perbedaan perubahan kadar glukosa darah puasa $(p>0,05)$ antara kelompok obesitas hipertensi $(-2.88 \pm 6.35 \mathrm{mg} / \mathrm{dl})$ dan kelompok obesitas nonhipertensi $(-6.33 \pm 4.67 \mathrm{mg} / \mathrm{dl})$.

Perbedaan Tekanan Darah Sistolik Sebelum dan Setelah Intervensi

Tabel perbedaan tekanan darah sistolik sebelum dan setelah intervensi disajikan untuk melihat perubahan rerata tekanan darah sistolik kelompok obesitas hipertensi dan obesitas nonhipertensi sebelum dan setelah pemberian puding kacang merah selama 14 hari.

Tabel 3. Perbedaan Tekanan Darah Sistolik Sebelum dan Setelah Intervensi

\begin{tabular}{|c|c|c|c|c|c|}
\hline \multirow[b]{2}{*}{ Variabel } & \multicolumn{2}{|c|}{ Tekanan Darah Sistolik } & \multicolumn{3}{|c|}{$\Delta$ Tekanan } \\
\hline & $\begin{array}{c}\text { Sebelum intervensi } \\
(\mathrm{mmHg})\end{array}$ & $\begin{array}{l}\text { Setelah intervensi } \\
(\mathrm{mmHg})\end{array}$ & $p^{\mathbf{a}}$ & $\begin{array}{c}\text { Darah } \\
\text { Sistolik }\end{array}$ & $p^{\mathbf{b}}$ \\
\hline $\begin{array}{l}\text { Obesitas } \\
\text { hipertensi } \\
(n=9)\end{array}$ & & & & & \\
\hline Mean \pm SD & $108.89 \pm 9.28$ & $106.67 \pm 7.07$ & 0.157 & $-2.22 \pm 4.41$ & $0 \Omega 06$ \\
\hline $\begin{array}{l}\text { Obesitas non- } \\
\text { hipertensi } \\
\text { Mean } \pm \text { SD }\end{array}$ & $125.00 \pm 5.47$ & $118.33 \pm 4.08$ & 0.046 & $-6.67 \pm 5.16$ & 0.096 \\
\hline
\end{tabular}

Tabel 3 menunjukkan pada kelompok obesitas hipertensi tidak mengalami penurunan tekanan darah sistolik $(p>0.05)$ setelah pemberian puding kacang merah selama 14 hari yaitu sebesar $2.22 \pm 4.41 \mathrm{mmHg}$. Kelompok obesitas nonhipertensi mengalami penurunan tekanan darah sistolik $(p<0.05)$ setelah pemberian puding kacang merah selama 14 hari yaitu sebesar $-6.67 \pm 5.16$ $\mathrm{mmHg}$.

Berdasarkan uji Mann-Whitney, tidak terdapat perubahan tekanan darah sistolik $(p>0.05)$ antara kelompok obesitas hipertensi $(-2.22 \pm 4.41$ $\mathrm{mmHg}$ ) dan kelompok obesitas non-hipertensi (6.67 $\pm 5.16 \mathrm{mmHg}$ ).

Perbedaan Tekanan Darah Diastolik Sebelum dan Setelah Intervensi

Tabel perbedaan tekanan darah diastolik sebelum dan setelah intervensi disajikan untuk melihat perubahan rerata tekanan darah diastolik kelompok obesitas hipertensi dan obesitas nonhipertensi sebelum dan setelah pemberian puding kacang merah selama 14 hari.

Tabel 4. Perbedaan Tekanan Darah Diastolik Sebelum dan Setelah Intervensi

\begin{tabular}{lccccc}
\hline \multirow{2}{*}{ Variabel } & \multicolumn{2}{c}{ Tekanan Darah Diastolik } & & $\begin{array}{c}\Delta \text { Tekanan } \\
\text { Darah } \\
\text { Diastolik }\end{array}$ & $\boldsymbol{p}^{\mathbf{b}}$ \\
\cline { 2 - 3 } $\begin{array}{l}\text { Sebelum intervensi } \\
\text { (mmHg) }\end{array}$ & $\begin{array}{c}\text { Setelah intervensi } \\
(\mathbf{m m H g})\end{array}$ & $\boldsymbol{p}^{\mathbf{a}}$ & & & \\
$\begin{array}{l}(\mathrm{m}=9) \\
\text { Mean } \pm \text { SD }\end{array}$ & $72.22 \pm 6.66$ & $68.89 \pm 3.33$ & 0.180 & $-3.33 \pm 7.07$ & 0.866 \\
\hline
\end{tabular}




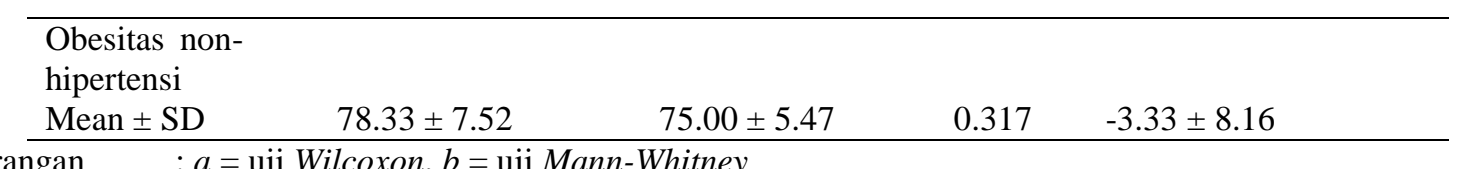
Keterangan $\quad: a=$ uji Wilcoxon, $b=$ uji Mann-Whitney

Tabel 4 menunjukkan pada kelompok obesitas hipertensi tidak mengalami penurunan tekanan darah diastolik $(p>0.05)$ setelah pemberian puding kacang merah selama 14 hari yaitu sebesar $3.33 \pm 7.07 \mathrm{mmHg}$. Kelompok obesitas nonhipertensi tidak mengalami penurunan tekanan darah diastolik $(p>0.05)$ setelah pemberian puding kacang merah selama 14 hari yaitu sebesar $-3.33 \pm$ $8.16 \mathrm{mmHg}$.

Berdasarkan uji Mann-Whitney, tidak terdapat perubahan tekanan darah diastolik $(p>0,05)$ antara kelompok obesitas hipertensi ($3.33 \pm 7.07 \mathrm{mmHg}$ ) dan kelompok obesitas nonhipertensi $(-3.33 \pm 8.16 \mathrm{mmHg})$.

Perbedaan Lingkar Pinggang Sebelum dan Setelah Intervensi

Tabel perbedaan lingkar pinggang sebelum dan setelah intervensi disajikan untuk melihat perubahan rerata lingkar pinggang kelompok obesitas hipertensi dan obesitas non-hipertensi sebelum dan setelah pemberian puding kacang merah selama 14 hari.

Tabel 5. Perbedaan Lingkar Pinggang Sebelum dan Setelah Intervensi

\begin{tabular}{|c|c|c|c|c|c|}
\hline \multirow[b]{2}{*}{ Variabel } & \multicolumn{2}{|c|}{ Lingkar Pinggang } & \multirow[b]{2}{*}{$p^{\mathbf{a}}$} & \multirow[b]{2}{*}{$\begin{array}{c}\Delta \text { Lingkar } \\
\text { Pinggang }\end{array}$} & \multirow[b]{2}{*}{$p P^{\mathrm{b}}$} \\
\hline & $\begin{array}{l}\text { Sebelum intervensi } \\
(\mathrm{cm})\end{array}$ & $\begin{array}{c}\text { Setelah intervensi } \\
(\mathbf{c m})\end{array}$ & & & \\
\hline $\begin{array}{l}\text { Obesitas } \\
\text { hipertensi } \\
(\mathrm{n}=9)\end{array}$ & & & & & \\
\hline Mean \pm SD & $88.89 \pm 1.94$ & $87.77 \pm 3.26$ & 0.165 & $-1.22 \pm 2.20$ & 0924 \\
\hline $\begin{array}{l}\text { Obesitas non } \\
\text { hipertensi } \\
\text { Mean } \pm \text { SD }\end{array}$ & $93.75 \pm 4.31$ & $92.00 \pm 5.10$ & 0.073 & $-1.75 \pm 1.89$ & \\
\hline
\end{tabular}

Keterangan $\quad: \mathrm{a}=$ paired $t$-test, $\mathrm{b}=$ independent $t$-test

Tabel 5 menunjukkan bahwa pada kelompok obesitas hipertensi tidak mengalami penurunan lingkar pinggang $(p>0.05)$ setelah pemberian puding kacang merah selama 14 hari yaitu sebesar $-1.22 \pm 2.20 \mathrm{~cm}$. Kelompok obesitas non-hipertensi tidak mengalami penurunan lingkar pinggang $(p>0.05)$ setelah pemberian puding kacang merah selama 14 hari yaitu sebesar $-1.75 \pm$ $1.89 \mathrm{~cm}$.
Berdasarkan uji Mann-Whitney, tidak terdapat perubahan lingkar pinggang $(p>0,05)$ antara kelompok obesitas hipertensi $(-1.22 \pm 2.20$ $\mathrm{cm})$ dan kelompok obesitas non-hipertensi $(-1.75 \pm$ $1.89 \mathrm{~cm}$ ).

\section{Asupan Makan Selama Intervensi}

Data asupan makan selama intervensi disajikan untuk melihat perbedaan asupan makan subjek selama intervensi pada kelompok obesitas hipertensi dan obesitas non-hipertensi.

Tabel 6. Asupan Makan Selama Intervensi

\begin{tabular}{|c|c|c|c|c|c|}
\hline Variabel & $\begin{array}{c}\text { Obesitas } \\
\text { hipertensi } \\
(n=9)\end{array}$ & $\begin{array}{c}\text { Tingkat } \\
\text { Kecukupan }\end{array}$ & $\begin{array}{c}\text { Obesitas non- } \\
\text { hipertensi } \\
(\mathrm{n}=6)\end{array}$ & $\begin{array}{c}\text { Tingkat } \\
\text { Kecukupan }\end{array}$ & $p$ \\
\hline & Mean \pm SD & & Mean \pm SD & & \\
\hline $\begin{array}{l}\text { Asupan } \\
\text { energi }\end{array}$ & $1.646 \pm 146.17$ & $50.5 \%$ & $1.639 \pm 165.58$ & $55.1 \%$ & $0.938^{\mathrm{a}}$ \\
\hline $\begin{array}{l}\text { Asupan } \\
\text { protein }\end{array}$ & $65.27 \pm 8.94$ & $66.1 \%$ & $85.56 \pm 43.03$ & $70.1 \%$ & $0.194^{\mathrm{b}}$ \\
\hline $\begin{array}{l}\text { Asupan } \\
\text { lemak }\end{array}$ & $60.41 \pm 45.05$ & $81.5 \%$ & $42.76 \pm 8.74$ & $65.5 \%$ & $0.157^{b}$ \\
\hline $\begin{array}{l}\text { Asupan } \\
\text { karbohidrat }\end{array}$ & $216.21 \pm 20.66$ & $49.5 \%$ & $221.36 \pm 20.23$ & $52 \%$ & $0.641^{\mathrm{a}}$ \\
\hline Asupan serat & $22.82 \pm 1.95$ & $60.4 \%$ & $30.00 \pm 15.40$ & $52.4 \%$ & $0.194^{\mathrm{b}}$ \\
\hline $\begin{array}{l}\text { Asupan } \\
\text { PUFA }\end{array}$ & $5.44 \pm 1.35$ & $30.5 \%$ & $4.61 \pm 0.91$ & $33.5 \%$ & $0.215^{\mathrm{a}}$ \\
\hline
\end{tabular}




\begin{tabular}{lccccc}
\hline $\begin{array}{l}\text { Asupan } \\
\text { natrium }\end{array}$ & $829.80 \pm 307.87$ & $66.1 \%$ & $995.05 \pm 403.21$ & $70.1 \%$ & $0.384^{\mathrm{a}}$ \\
\hline $\begin{array}{l}\text { Asupan } \\
\text { kalium }\end{array}$ & $1.553 \pm 153.96$ & $21.6 \%$ & $1.516 \pm 399.61$ & $22.7 \%$ & $0.808^{\mathrm{a}}$ \\
\hline $\begin{array}{l}\text { Asupan } \\
\text { kalsium }\end{array}$ & $438.23 \pm 113.23$ & $23.8 \%$ & $477.90 \pm 149.10$ & $27.7 \%$ & $0.346^{\mathrm{b}}$ \\
\hline $\begin{array}{l}\text { Asupan } \\
\text { magnesium }\end{array}$ & $171.62 \pm 15.82$ & $59 \%$ & $203.06 \pm 78.88$ & $54.7 \%$ & $0.053^{\mathrm{a}}$ \\
\hline
\end{tabular}

Keterangan $\quad: \mathrm{a}=$ independent $t$-test, $\mathrm{b}=$ uji Mann-Whitney

Tabel 6 menunjukkan tidak terdapat perbedaan asupan energi, protein, lemak, karbohidrat, serat, PUFA, natrium, kalium, kalsium dan magnesium antara kelompok obesitas hipertensi dan obesitas non-hipertensi selama intervensi $(p>0.05)$.

\section{PEMBAHASAN}

Tidak terdapat perbedaan karakteristik rerata usia, IMT dan aktifitas fisik

yang bermakna antara kelompok obesitas hipertensi dan obesitas non-hipertensi yang menunjukkan bahwa subjek penelitian adalah homogen. Seluruh subjek dalam penelitian ini adalah wanita, karena kadar gula darah wanita cenderung lebih tinggi dari pria akibat komposisi lemak tubuh yang lebih tinggi dan aktifitas fisik yang lebih rendah sehingga lebih rentan mengalami kegemukan. ${ }^{23}$ Usia subjek pada penelitian ini sebagian besar berada pada kelompok umur 16 tahun. Risiko menderita gangguan toleransi glukosa semakin meningkat seiring bertambahnya usia.

Berdasarkan IMT, keseluruhan subjek termasuk dalam kategori obesitas Berdasarkan uji statistik, tidak terdapat perbedaan IMT antara kelompok kelompok obesitas hipertensi dan obesitas non-hipertensi $(p>0.05)$. Resistensi insulin pada penderita obesitas sentral terjadi karena lemak viseral berperan dalam serangkaian perubahan sekresi adipokin yang menghasilkan sejumlah sitokin pro-inflamasi seperti Tumor Necrosis Factors (TNF- $\alpha$ ), Interleukin-1 (IL-1) dan IL-6 yang dapat mengganggu aktifitas normal insulin dalam sel lemak dan sel otot serta toksisitas pada sel- $\beta$ pankreas. Selain itu, terjadi peningkatan kadar asam lemak dalam darah dan peningkatan produksi glukosa hepatik akibat penumpukan lemak dalam hati sehingga meningkatkan risiko terjadinya DM tipe II. ${ }^{24}$

Berdasarkan hasil uji statistik tidak ditemukan adanya perbedaan kadar GDP yang signifikan antara kelompok obesitas hipertensi dan obesitas non-hipertensi sebelum intervensi, sehingga dapat dikatakan kadar GDP kedua kelompok adalah homogen. Menurut American
Diabetic Association, seseorang termasuk dalam kategori prediabetes apabila memiliki kadar GDP $100-125 \mathrm{mg} / \mathrm{dl}^{25}$, akan tetapi pada kedua kelompok belum terjadi gangguan toleransi glukosa ditandai dengan kadar GDP $<100 \mathrm{mg} / \mathrm{dl}$. Secara statistik, terdapat perbedaan perubahan kadar GDP pada kelompok obesitas non-hipertensi. Hal ini menunjukkan ada pengaruh pemberian puding kacang merah sebanyak 50 gram selama 14 hari terhadap penurunan kadar GDP kelompok obesitas non-hipertensi.

Pada penelitian yang pernah dilakukan sebelumnya, pemberian makanan campuran antara karbohidrat sederhana yang dicampur dengan kacang merah (arem-arem isi kacang merah) pada pasien DM tipe 2 secara signifikan dapat menurunkan kadar gula darah puasa sebesar 45,5 $\mathrm{mg} / \mathrm{dl} \pm 16,63 .{ }^{26}$ Penelitian lain juga menunjukkan bahwa pemberian pakan kacang merah selama 4 minggu pada tikus wistar diabetik yang diinduksi alloxan menunjukkan penurunan kadar gula darah dari $217,87 \mathrm{mg} / \mathrm{dl}$ menjadi 57,70 mg/dl $(69 \%)$ sedangkan pada kacang kedelai menunjukkan penurunan kadar gula darah dari $218,94 \mathrm{mg} / \mathrm{dl}$ menjadi $76,82 \mathrm{mg} / \mathrm{dl}(65 \%) .{ }^{9}$ Hasil ini sesuai dengan indeks glikemiknya yaitu kacang merah 26 sedangkan kacang kedelai 31. Hal ini dikarenakan kacang merah memiliki viskositas yang lebih besar dan absorpsi yang lebih kecil. Terlihat bahwa kandungan serat pangan dan pati punya andil yang cukup besar karena kedua komponen ini cukup viskus dan mengurangi absorpsi seperti yang dilaporkan pada penelitian yang terdahulu. Kemampuan kacang merah dalam menurunkan kadar gula darah disebabkan karena kandungan seratnya yang tinggi, resistant starch (pati tahan cerna) yang tinggi dibandingkan dengan kacang kedelai, dan kadar amilosa yang tinggi menyebabkan nilai indeks glikemiknya rendah sehingga memberikan korelasi dalam penurunan kadar gula darah. ${ }^{9,27}$

Salah satu faktor yang menyebabkan kacang merah berperan dalam penurunan kadar gula darah adalah indeks glikemiknya yang rendah. ${ }^{27}$ Indeks glikemik kacang merah yang rendah banyak 
dipengaruhi oleh kadar serat, pati resisten, kadar amilosa dan proses pemasakan. ${ }^{8,27}$ Berbagai proses pemasakan atau pengolahan dapat mengubah struktur, dan komposisi kimia pangan yang selanjutnya mengubah daya serap dan indeks glikemik pangan. ${ }^{14}$ Prinsip proses pemasakan dengan cara dikukus dan direbus hampir sama yaitu melemahkan struktur dan pematangan jaringan yang menyebabkan makanan menjadi mudah diserap. Pengolahan dengan cara pengukusan tidak banyak terjadi perubahan pada zat gizinya tetapi akan terjadi penurunan kadar air sebanyak $8,32 \% .^{16}$ Proses pengolahan dengan cara dikukus cenderung mempertahankan zat gizi dan hanya sedikit menimbulkan kerusakan zat inhibitor. ${ }^{10,16}$

Peran puding kacang merah dalam menurunkan kadar glukosa darah gula darah adalah kandungan serat kacang merah. Jenis serat yang mempunyai efek penurunan kadar gula darah atau hipoglikemik adalah serat yang larut dalam air.

${ }^{8,28}$ Peran serat yang larut air berfungsi untuk meningkatkan kekentalan isi usus yang mengakibatkan terjadinya penurunan aktifitas $\alpha$ amilase dan menghambat penyerapan glukosa. ${ }^{12}$

Berdasarkan hasil uji statistik adanya perbedaan tekanan darah sistolik yang signifikan pada kelompok obesitas non-hipertensi setelah intervensi. Komponen protein dalam kacangkacangan seperti kacang merah yang dapat menjelaskan sifat antihipertensi adalah arginin. Hal ini mungkin karena kemampuan arginin untuk meningkatkan resistensi insulin, menurunkan bentuk produk advanced glycation end (AGE), meningkatkan nitrat oksida, dan meningkatkan penurunan angiotensin II dan stres oksidatif, dengan meningkatkan fungsi sel endotel dan penurunan resistensi pembuluh darah perifer. Arginin adalah asam amino semiessential yang merupakan substrat yang diperlukan dalam jalur oksida nitrat (NO), yang terlibat dalam sistem renin angiotensin (RAS), dan sebagian mengatur sekresi insulin. Sistem ini berperan dalam homeostasis tekanan darah dan kesehatan pembuluh darah. Meskipun arginin dapat dibentuk secara endogen, asupan makanan memberikan kontribusi untuk pasokan tubuh dan dapat mengatasi kekurangan atau perubahan dalam metabolisme arginin. Beberapa penelitian pada hewan dan beberapa studi pada manusia menunjukkan bahwa suplementasi arginine, baik dengan infus atau suplemen oral, menurunkan tekanan darah dan meningkatkan fungsi pembuluh darah. ${ }^{29,30}$

Penyerapan arginin dapat diatur oleh analog arginin, asymmetrical dimethyl arginine (ADMA). ${ }^{31,32}$ Cara lain dimana arginin mempengaruhi vasodilatasi adalah melalui insulin. Arginin mempromosikan pelepasan insulin dari selsel beta pankreas ${ }^{33}$ dan pada gilirannya, insulin menurunkan konsentrasi plasma $\mathrm{ADMA}^{34}$ dan merangsang ambilan arginin. ${ }^{35,36}$ Pengikatan insulin pada reseptor insulin merangsang produksi NO melalui aktivasi jalur insulin-signaling ${ }^{37}$ yang mengakibatkan vasodilatasi yang dimediasi insulin. Arginin juga memodulasi RAS. Ini menghambat aktivitas $\mathrm{ACE}^{38}$, sehingga menurunkan AII. Efek arginin pada sistem renin angiotensin RAS mungkin dimediasi insulin. ${ }^{39}$ Secara statistik, tidak terdapat perbedaan perubahan tekanan darah sistolik antara kelompok obesitas hipertensi dengan obesitas nonhipertensi. Berdasarkan hasil uji statistik tidak ditemukan adanya perbedaan tekanan darah diastolik yang signifikan antara kelompok obesitas hipertensi dengan obesitas non-hipertensi.

Tekanan darah diastolik pada kedua kelompok cenderung stabil, sehingga tidak terdapat perbedaan perubahan tekanan darah diastolik antara kelompok obesitas hipertensi dengan obesitas non-hipertensi.

Berdasarkan hasil uji statistik tidak adanya perbedaan lingkar pinggang yang signifikan antara kelompok obesitas hipertensi dengan obesitas nonhipertensi. Lingkar pinggang merupakan prediktor resistensi insulin dan hipertensi pada anak dan remaja, dimana resistensi insulin sendiri berperan besar untuk terjadinya sindrom metabolik. ${ }^{40,41}$ Penelitian lain mendapatkan bahwa meskipun lingkar pinggang merupakan prediktor sindrom metabolik, tetapi hasilnya tidak lebih baik dibandingkan IMT. ${ }^{42}$ Serat tidak larut pada kacang merah mempunyai kemampuan untuk mengisi lambung, memperlambat pengosongan lambung, dan merubah peristaltik lambung, sehingga hal tersebut dapat menimbulkan rasa kenyang yang lebih lama dan menyebabkan keterlambatan penyampaian zat gizi ke usus halus. Secara statistik, tidak terdapat perbedaan perubahan lingkar pinggang antara kelompok obesitas hipertensi dengan obesitas non-hipertensi.

Asupan makan subjek selama intervensi termasuk dalam kategori kurang. Hal ini dapat disebabkan the flat slope syndrome, yaitu kecenderungan bagi responden yang gemuk untuk melaporkan lebih sedikit asupan yang dimakan.

\section{SIMPULAN}

Ada pengaruh puding kacang merah terhadap kadar GDP dan tekanan darah sistolik pada kelompok obesitas non-hipertensi. Tidak ada pengaruh puding kacang merah terhadap kadar GDP dan tekanan darah sistolik pada kelompok obesitas hipertensi. Tidak ada pengaruh puding kacang 
merah terhadap tekanan darah diastolik dan lingkar pinggang pada kelompok obesitas hipertensi dan obesitas non-hipertensi.

\section{SARAN}

Melanjutkan penelitian dengan desain penelitian yang berbeda untuk melihat efektifitas dari puding kacang merah.

\section{DAFTAR PUSTAKA}

1. Grundy SM, Brewer HB, Cleeman JI, Smith SC, Lenfant C. Definition of metabolic syndrome: report of the National Heart, Lung, and Blood Institute/American Heart Association conference on scientific issues related to definition. Circulation AHA 2004; 109: 433-8

2. International Diabetes Federation. Definition of the metabolic syndrome in children and adolescent. 2007.

3. Thaman RG, Arora GP. Metabolic Syndrome: Definition and pathophysiology the discussion goes on. J Phys. \& Pharmaco. 2013; 3(3):48-56.

4. Dwipayana MP, Suastika K, Saraswati IMR, Gotera W, Budhiarta AAG, Sutanegara, et al. Prevalensi sindroma metabolik pada populasi penduduk Bali, Indonesia. Bag. Ilmu Penyakit Dalam FK Udayana Denpasar. Bali. 2011.

5. Badan Penelitian dan Pengembangan Kesehatan Kementerian Kesehatan RI. Kecenderungan Prevalensi Obesitas Sentral Penduduk Umur $\geq 15$ tahun menurut Provinsi, Indonesia 2007 dan 2013. Riset Kesehatan Dasar (Riskesdas) 2013.

6. Misra A, Shrivatava U. Obesity \& dyslipidemia in South Asians. J Nutr 2013; 5:2708-2733.

7. Daniels SR, Arnett DK, Eckel RH, Gidding SS. Overweight in children and adolescents, pathophysiology, consequence, prevention, and treatment. Circulation 2005; 111: 1999-2012.

8. Rimbawan, Siagian A. Indeks glikemik pangan: cara mudah memilih pangan yang menyehatkan. Jakarta: Penebar Swadaya; 2004.

9. Marsono Y, Zuheid N, Fitri R. Pengaruh diet kacang merah terhadap kadar gula darah tikus diabetik induksi alloxan. Yogyakarta: Universitas Gajah Mada; 2002.

10. Made A. Sehat dengan hidangan kacang dan bijibijian. Jakarta: Penebar Swadaya; 2009.

11. Nurfi A. Kacang merah turunkan kolesterol dan gula darah. Jakarta: Depkes RI.

12. Budiyanto. Gizi dan kesehatan. Malang: Bayu Media dan UMM Press; 2002.

13. Groff JL, Gropper SS, Hunt SM. Dietary fiber: advance nutrition and human metabolism. Los Angeles, New York: 1995. hal. 102-11.

14. Balai Besar Penelitian dan Pengembangan Pasca Panen. Sehat dengan pangan indeks glikemik rendah. Bogor: Warta Penelitian dan Pengembangan Pertanian; 2007.Vol 29.No3.
15. Intarina $\mathrm{H}$, editor. Seri penganan jadul tetap favorit. Jakarta: PT Gramedia Pustaka Utama; 2013.

16. Teguh B. Perubahan fenolik, antosianin, dan aktifitas antioksidan ubi ungu (Diascorea Alata L) akibat proses pengolahan. (Tesis). Semarang: UNDIP; 2009.

17. Pennington J. Supplementary tables-amino acids. In: Allen A, ed. Bowes \& Church's Food Values of Portions Commonly Used, 16th ed. Philadelphia: JB Lippincott Company, 1994:A325-77.

18. Guoyao W, Morris SM. Arginine metabolism: nitric oxide and beyond. Biochem 1998;J 336:1-17.

19. S Vasdev, V Gill. The antihypertensive effect of arginine. Int J Angiol 2008;17(1):7-22.

20. Sastroasmoro S, Ismael S. Dasar metodologi penelitian klinis. Edisi ke-2. Jakarta: CV Agung Seto, 2002.

21. Mexitalia M, Utari A, Sakundarno M, Yamauchi T, Subagio HW, Soemantri A. Sindroma metabolik pada remaja obesitas. Media Medik Indo 2009; 43(6):300-06.

22. Supariasa, Ibnu Fajar, dkk. Penilaian status gizi. Jakarta: Badan Penerbit Kedokteran EGC; 2001.

23. Soegondo S, Soewondo P, Subekti I. Penatalaksanaan diabetes melitus terpadu. Jakarta: Pusat Diabetes dan Lipid RSUP Nasional Dr. Cipto Mangunkusumo Fakultas Kedokteran Universitas Indonesia; 2002

24. Mlinar B, Marc J, Janez A, Pfeifer M. Molecular mechanisms of insulin resistance and associated diseases. 375 (2007); 20-35.

25. American Diabetic Association. Standards of medical care in diabetes. 2012. [cited 2013 March 7th]. Available from URL: http://care.diabetesjournals.org/content/35/Supple ment_1/S11.full.pdf+html

26. Herni A. Indeks glikemik makanan campuran pada pasien DM tipe 2 di RSUP Dr. Sardjito Yogyakarta Kajian Indeks Glikemik Observasi dan Perhitungan. Yogyakarta: UGM; 2004.

27. Marsono Y. Penentuan indeks glikemik kacangkacangan, faktor determinan, dan efek hipoglisemiknya (KTI). Yogyakarta: UGM; 2002.

28. Chandalia M, Abimanya G, Lutjohann D, Bergmann KV, Grundi SM, Brinkley LJ. Beneficial of high dietary fiber intake in patient with type 2 diabetes and hypercholesterolemia. Am J Clin Nutr 1999; 70(4):466-73.

29. Zhou MS, Kosaka H, Tian RX, et al. L-arginine improves endothelial function in renal artery of hypertensive Dahl rats. J Hypertens 2001; 19:4219.

30. Fujii S, Zhang L, Igarashi J, Kosaka H. L-arginine reverses p47phox and gp91phox expression induced by high salt in Dahl rats. Hypertension 2003; 42:1014-20.

31. Closs EI, Basha FZ, Habermeier A, Forstermann U. Interference of L-arginine analogues with Larginine transport mediated by the y+carrier hCAT2B. Nitric Oxide 1997; 1:65-73. 
32. Brunini T, Moss M, Siqueira M, et al. Inhibition of 1-arginine transport in platelets by asymmetric dimethylarginine and $\mathrm{N}$-monomethyl-l-arginine: Effects of arterial hypertension. Clin Exp Pharmacol Physiol 2004; 31:738-40.

33. Sener A, Best LC, Yates AP, et al. Stimulussecretion coupling of arginine-induced insulin release: Comparison between the cationic amino acid and its methyl ester. Endocrine 2000; 13:32940.

34. Eid HM, Reims H, Arnesen H, Kjeldsen SE, Lyberg T, Seljeflot I. Decreased levels of asymmetric dimethylarginine during acute hyperinsulinemia. Metabolism 2007; 56:464-9.

35. Sobrevia L, Nadal A, Yudilevich DL, Mann GE. Activation of Larginine transport (system $\mathrm{y}+$ ) and nitric oxide synthase by elevated glucose and insulin in human endothelial cells. J Physiol 1996; 490:775-81.

36. Mann GE, Yudilevich DL, Sobrevia L. Regulation of amino acid and glucose transporters in endothelial and smooth muscle cells. Physiol Rev 2003; 83:183-252.

37. Zeng G, Nystrom FH, Ravichandran LV, et al. Roles for insulin receptor, PI3-kinase, and akt in insulin-signaling pathways related to production of nitric oxide in human vascular endothelial cells. Circulation 2000; 101:1539-45.

38. Higashi $\mathrm{Y}$, Oshima $\mathrm{T}$, Ono $\mathrm{N}$, et al. Intravenous administration of L-arginine inhibits angiotensinconverting enzyme in humans. J Clin Endocrinol Metab 1995; 80:2198-202.

39. Kamide K, Rakugi H, Nagai M, et al. Insulinmediated regulation of the endothelial reninangiotensin system and vascular cell growth. J Hypertens 2004; 22:121-7.

40. Hirschler V, Aranda C, Lujan Calcagno M, Maccalini G, Jadzinsky M. Can waist circumference identify children with the metabolic syndrome? Arch Pediatr Adolesc Med. 2005; 159:740-4.

41. Weiss R, Dziura J, Burget TS, Tamborlane WV, Taksali SE, Yeckel CW, et al. Obesity and the metabolic syndrome in children and adolescents. N Engl J Med. 2004; 350:2362-74.

42. Denney-Wilson E, Hardy LL, Dobbins T, Okely $\mathrm{AD}$, Baur LA. Body mass index, waist circumference, and chronic disease risk factors in Australian adolescents. Arch Pediatr Adolesc Med. 2008; 162(6):566-73. 